\title{
EFFECT OF SAWDUST ASH AND EGGSHELL ASH ON SELECTED ENGINEERING PROPERTIES OF LATERALIZED BRICKS FOR LOW COST HOUSING
}

\author{
A. L. Ayodele ${ }^{1, *}$, O. M. Oketope ${ }^{2}$ and O. S. Olatunde ${ }^{3}$ \\ 1, 2, 3, Department of Civil Engineering, Obafemi Awolowo University, Ile IfE, Osun StaTe, NIGERIA \\ E-mail addresses: ${ }^{1}$ adekemiayodele@ymail.com, 2 funshurr@yahoo.com, \\ 3 asiwaju0442@gmail.com
}

\begin{abstract}
A study of the property of laterite bricks stabilized with Egg Shell Ash (ESA) and Saw Dust Ash (SDA) in relation to that stabilized with cement was conducted, this was with a view to obtaining an economic replacement for cement. Laterite was stabilized using 0, 2, 4, 8 and 16\% (by weight of dry soil) of a mixture of ESA and SDA. The laterite was also stabilized with $5 \%$ (by weight of dry soil) of cement to serve as control. For each of these mixes, OMC and MDD of stabilized laterite and compressive strength ( $\left.q_{u}\right)$ of bricks made from stabilized laterite were determined. The results obtained were $47 \%$ calcium oxide in ESA, $59.8 \%$ silica in SDA, optimum MDD of $1.75 \mathrm{~kg} / \mathrm{m}^{3}$, OMC of $19.0 \%$ for laterite and optimum of $1.2 \mathrm{~N} / \mathrm{mm}^{2}$ for ash stabilized laterite bricks. The optimum results were obtained for ash content of 2 and $4 \%$. The maximum $q_{\nu}$ obtained for cement stabilized brick was however $2.1 \mathrm{~N} / \mathrm{mm}^{2}$. In conclusion, SDA and ESA can be a substitute for cement in low cost housing.
\end{abstract}

Keywords: compressive strength, laterite, stabilization, adobe bricks, pozolan

\section{INTRODUCTION}

Shelter is a necessity for all humans regardless of predominant socio-economic conditions. Laterites/lateritic soils are the most common materials for the construction of earth dams, low cost houses, highways; airfields, embankments as well as foundation material to support structures in tropical and subtropical regions of the world [1]. There are however, some cases where the properties of the available lateritic soils near the construction works do not meet the required specifications. The use of modified soil is therefore considered in lieu of replacing such soils with selected material from a distant source. Additives are added in small quantities in order to modify and improve the properties of soils used in fills, increase erosion resistance, reduce permeability or provide temporary stability during construction. Commonly used additives in soil modification include fly ash, slag, asphalt, resins, Portland cement, organic chemicals. Different types of additives have been used in the past by different researchers [2 - 7] to improve the properties of lateritic soil. The use of natural pozollanas such as volcanic ash, rice husks ash, saw dust ash, slag has been explored $[8,9]$. Pozollana can be defined as siliceous and/or aluminous materials which in themselves do not possess cementitious properties but when combined with calcium (from lime or Portland cement) can form cementitious compounds. The use of pozollana can reduce the amount of Portland cement or lime required for stabilization.

There has been a large amount of interest and subsequent research into the use of interlocking mud bricks as an economical and environmentally sound method of satisfying the housing demand in many countries, particularly in Nigeria. Mud bricks perform considerably better, in environmental terms, than fired bricks. They have significantly less embodied energy, contribute fewer $\mathrm{CO}_{2}$ emissions and help to promote the local economy and local labour. At first glance they appear to be an ideal choice for an economically viable sustainable construction material. However, the major

* Corresponding author, tel: +234-803-407- 4666 
drawback of unfired mud bricks is that they tend to be less durable than their fired counterparts and are more susceptible to water damage. Traditionally, unfired mud bricks have been stabilized with cement to overcome these short comings but the use of cement reduces the environmental differential between unfired bricks and fired ones. Research into alternative stabilizers is both relevant and necessary to ensure unfired mud bricks remain a competitive alternative to modern construction methods.

The effect of sawdust ash (SDA) and egg shell ash (ESA) on selected engineering properties of lateralized bricks for low cost building is scarce in literature and not much has been done on its use as sustainable alternative to cement for the stabilization of unfired bricks and how economical content of cement for stabilization can be improved. In this work, ESA was explored as a good source of calcium which can beneficially react with siliceous compounds in SDA. According to [10], the main compound in eggshell $(95 \%)$ is calcium carbonate $\left(\mathrm{CaCO}_{3}\right)$.

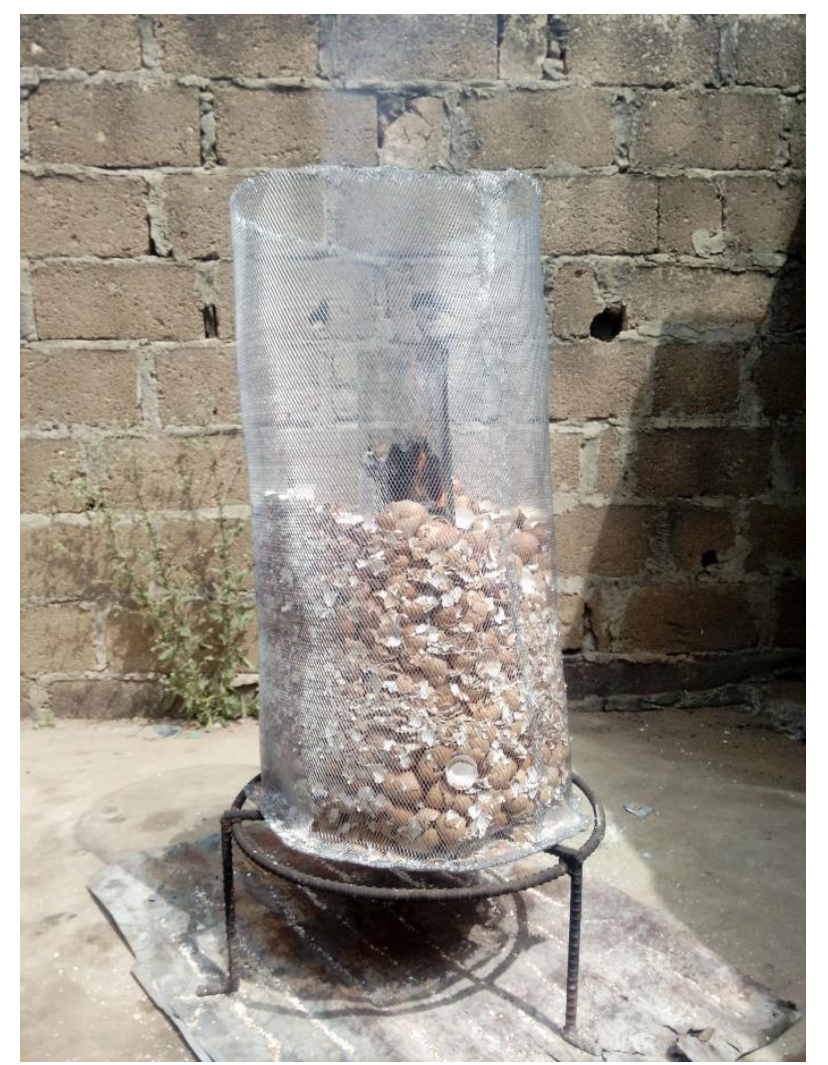

Figure 1: Locally fabricated basket burner

\section{MATERIALS AND METHODS}

Disturbed laterite soil was collected from an existing borrow pit (with GPS location 4038'43" $\mathrm{E}, 7^{0} 36^{\prime} 13^{\prime \prime} \mathrm{N}$ ) in Ile-Ife, Osun state and taken to the geotechnical engineering laboratory, department of Civil
Engineering, OAU where it was air dried. Saw dust was collected from a saw mill at Oke Ayepe area, Osogbo, Osun state, it was air dried and calcined into ash in a locally fabricated furnace (basket burner presented in Figure 1) at a temperature of not greater than $650^{\circ} \mathrm{C}$. The saw dust ash (SDA) passing sieve with opening $600 \mu \mathrm{m}$ was used for the tests, the particles retained were discarded. Egg shells were also collected, washed and air dried. The air dried egg shell was also calcined in a similar way as saw dust to produce the egg shell ash (ESA) used for the study. Portland cement was procured from a cement depot in Ile-Ife. Tap water was used for brick production and distilled water was used for $\mathrm{pH}$ test.

Preliminary tests carried out included specific gravity, $\mathrm{pH}$, liquid limit, plastic limit, and particle size distribution of the soil sample in accordance with BS 1377-2. The specific gravity and $\mathrm{pH}$ of SDA and ESA were also determined using standard methods. SDA and ESA were subjected to chemical spectrometric analysis to determine some of their mineralogical composition.

Laboratory compaction test using the West Africa method to determine the optimum moisture content (OMC) and maximum dry density (MDD) of the laterite was carried out according to ASTM D 698. The laterite was then mixed with different percentages $(2,4,8$ and $16 \%$ by weight of dry soil) of a combination of both SDA and ESA. Equal amount of SDA and ESA were mixed together. The OMC and MDD of each lateriteash mix were then determined using West Africa method of compaction method. The laterite soil was also mixed with only $5 \%$ (by weight of dry soil) of cement. OMC and MDD of the laterite-cement mix were determined, also, using West Africa compaction method. Laterite-cement mix served as the control to have basis for comparison. It has been established in Literature that $5 \%$ of cement is enough to stabilize laterite [11].

Pure laterite, laterite-ash mix and laterite-cement mix were mixed with their corresponding OMCs and press machine was used to produce bricks of size $291 \mathrm{~mm} x$ $138 \mathrm{~mm} \times 115 \mathrm{~mm}$ from the different mixes. The bricks were produced by pouring appropriate laterite mixes into the mould and tamping the mix with a $20 \mathrm{~cm}$ diameter rod. A hinged weight of $15 \mathrm{~kg}$ was dropped six times from a height of $30 \mathrm{~cm}$ onto the exposed top of the mix in the mould to give equivalent pressure of $3 \mathrm{~N} / \mathrm{mm}^{2}$ followed by effective pressing. The $\mathrm{pH}$ of each mix was determined. After production, each brick was weighed to determine its density. The bricks 
were cured for 14, 21, 28 and 90 days. Curing was done by covering the bricks (which were laid on a flat surface in the laboratory) with polythene bag to avoid moisture loss. The compressive strength and $\mathrm{pH}$ of each brick was determined after curing.

The data obtained was used to determine the optimum percentage of SDA and ESA required for stabilization. The data were also subjected statistical analysis using analysis of variance (ANOVA) to determine the significance or otherwise of the percentages of ash and curing age on the $\mathrm{pH}$ and compressive strength of the bricks.

\section{RESULTS AND DISCUSSION}

\subsection{Preliminary Analysis of Laterite}

The results of preliminary analyses of the laterite is presented in Table 1 . The specific gravity (G) of the laterite soil is 2.72. This conforms with [12] which specifies that $\mathrm{G}$ of lateritic soil was to be between 2.6 to 2.9. According to [12], a soil is clayey if the fine fraction has plasticity index of $11 \%$ or more, thus the laterite soil for this study is not clayey soil because the $\mathrm{PI}$ is less than $11 \%$.

\subsection{Preliminary and Chemical Analysis of SDA and ESA}

The specific gravity of SDA is 2.22 which conforms to that of [13]. The specific gravity of ESA is 2.38. The $\mathrm{pH}$ value of SDA is 12.15 and that of ESA is 13.29. This shows that they are basic, and it implies that the ashes can react together in presence of moisture to form cementitious compound. This is because high basic environment is required for the formation of cementitious compounds [14]. The results of chemical analysis of SDA and ESA are presented in Table 2. The results show that SDA has high silica content, this is similar to that obtained by [13] and [15]. The percentage of a combination of both $\mathrm{Fe}_{2} \mathrm{O}_{3}$ and $\mathrm{SiO}_{2}$ in the later, [15], was $68.8 \%$ while the percentage for the SDA used in this study is $62.032 \%$. SDA can thus be used as a pozzolan. The calcium content in ESA is much higher than that in SDA, the total calcium content in the combined of ESA and SDA is $54.11 \%$ which compares relatively well to the calcium content in cement. These results of chemical analysis show that a combination of SDA and ESA can cause cementation of the compacted laterite and laterite bricks, when the calcium in ESA reacts with silica in SDA.

\subsection{Compaction Properties of Stabilized Laterite} The maximum dry density (MDD) and optimum moisture content (OMC) are presented in Figure 2. There was increase in the MDD as the percentage of ashes increased up to $4 \%$, there was decrease in MDD beyond $4 \%$ ash content. The increase in MDD can be attributed to filling of the voids in lateritic soil with ash (which are finer than the laterite particles). As the percentage of ashes increased to 8 and $16 \%$, there was reduction in the MDD of the soil. This reduction can be attributed to replacement of laterite with ashes, but since the ash has a lower specific gravity than the laterite, there was a reduction in MDD. Increase in ash content led to initial reduction in the OMC of soil. As ash content increased beyond $4 \%$, there was increase in $\mathrm{OMC}$ as more moisture is required for hydration reaction to take place. It shows that increase in OMC was attributed to increase in surface area of the fine particles in the mixture [16].

Table 2: Chemical Constituents of the Mixture of SDA and ESA Compare to Cement

\begin{tabular}{lllll}
\hline $\begin{array}{l}\text { Compound } \\
(\%)\end{array}$ & SDA & ESA & $\begin{array}{l}\text { SDA } \\
\text { ESA }\end{array}$ & Cement \\
\hline $\mathrm{CaO}$ & 6.901 & 47.205 & 54.106 & 63.81 \\
$\mathrm{MgO}$ & 0.057 & 0.097 & 0.154 & 2.42 \\
$\mathrm{Fe}_{2} \mathrm{O}_{3}$ & 2.231 & 0.511 & 2.742 & 3.07 \\
$\mathrm{SiO}_{2}$ & 59.801 & 0.162 & 59.962 & 21.45 \\
\hline
\end{tabular}

Table 1: Results of Preliminary Analysis of Laterite

\begin{tabular}{ll}
\hline Property & value \\
\hline Specific Gravity (G) & 2.72 \\
pH & 4.07 \\
Liquid limit (\%) & 49 \\
Plastic limit & 40 \\
Plasticity index (\%) & 9 \\
Percent passing sieve No. 200 (\%) & 47.7 \\
Percent passing sieve No. $40(\%)$ & 78.1 \\
\hline
\end{tabular}

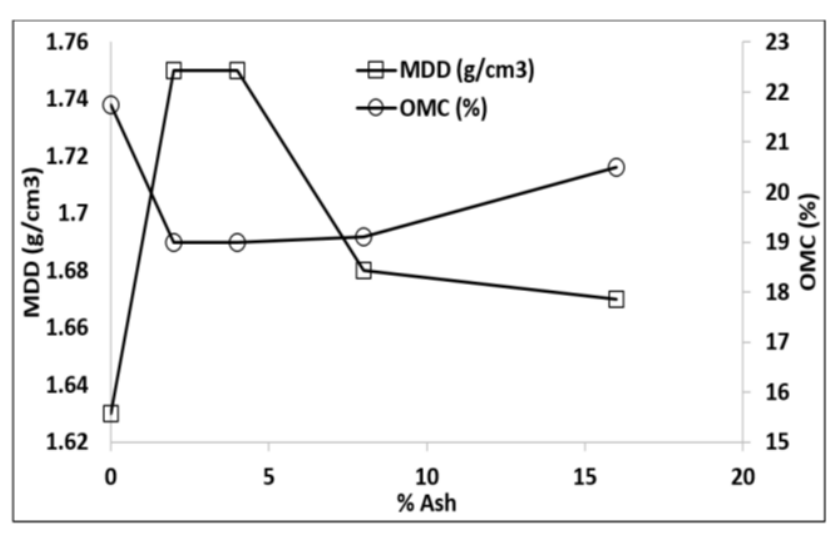

Figure 2: Compaction properties of SDA and ESA treated laterite 


\section{4 pH of Stabilized Laterite Bricks}

It was important to determine the $\mathrm{pH}$ of stabilized laterite because [14] showed that $\mathrm{pH}$ plays an important role in the formation of cementitious compounds when laterites are stabilized. The addition of ESA and SDA led to increase in the $\mathrm{pH}$ of laterite bricks at all concentrations of ash as presented in Figure 3. The laterite which was acidic in nature (as presented in Table 1), became basic on addition of ash (at all percentages). Figure 3 also shows that as the curing age increased, the $\mathrm{pH}$ of the laterite bricks increased. The average $\mathrm{pH}$ value of the bricks mixed with $16 \%$ of ashes at 90 days curing was 10.71 which is an indication that increase in percentage of ashes and curing days makes the bricks more basic. Statistical analysis shows that both percentage of ash and curing age have significant effect on the $\mathrm{pH}$ with $p$ values of $2.24 \times 10^{-10}$ and $9.46 \times 10^{-5}$, respectively.

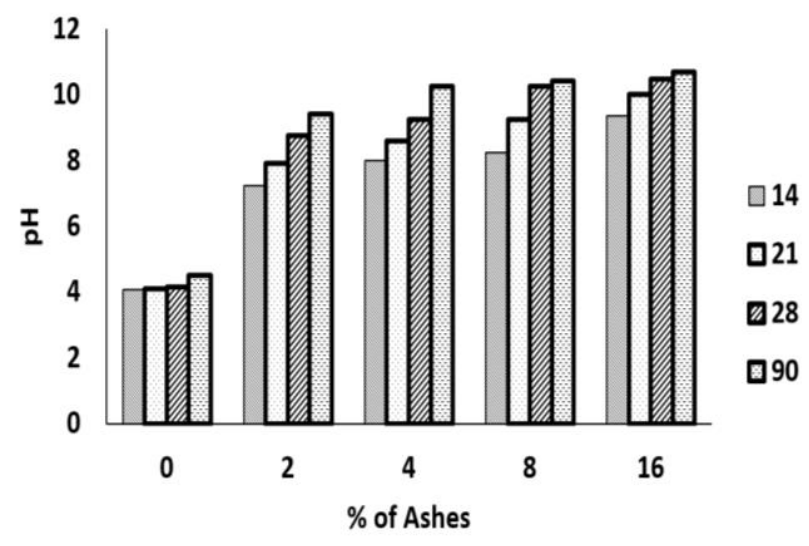

Figure 3: pH of stabilized bricks at different curing ages

\subsection{Dry density of Laterite Bricks}

Minimum and maximum density of 1489 and 1749 $\mathrm{kg} / \mathrm{m}^{3}$, respectively were obtained for the bricks.
These values are smaller than $1810 \mathrm{~kg} / \mathrm{m}^{3}$ which is the minimum specification by [11] for laterite bricks, although [18] specified a minimum of $1500 \mathrm{~kg} / \mathrm{m}^{3}$ for first grade sandcrete blocks. These results (presented in Figure 4), show that more pressure is required to produce the bricks to achieve the specified standard.

\subsection{Compressive strength of Stabilized Bricks}

According to [11], lateritic bricks with maximum Portland cement content of $5 \%$ mix by dry weight should have minimum compressive strength of 1.65 $\mathrm{N} / \mathrm{mm}^{2}$ before curing and $1.8 \mathrm{~N} / \mathrm{mm}^{2}$ after curing for 28 days. Such bricks can be used for the construction of bungalow.

The compressive strengths $\left(\mathrm{q}_{\mathrm{u}}\right)$ of laterite bricks cured for 14, 21, 28 and 90 days are presented in Figure 5. The results show a consistent increase in the $q_{u}$ of cement stabilized laterite as curing age increased. There are no consistent patterns in the $q_{u}$ of SDA and ESA stabilized laterite, there is, however, consistent reduction in $q_{u}$ at 21 days of curing when compared to 14 and 28 days of curing. [18] affirmed that when some pozzlanic materials of low chemical activity are used to replace cement on an equal volume basis, early strengths may be reduced. It can be observed from Figure 2 and 3 that bricks with $2 \%$ and $4 \%$ ash (with the highest MDD) have maximum $q_{u}$ while bricks with $8 \%$ and $16 \%$ ash (with lowest MDD) have low $\mathrm{q}_{\mathrm{u}}$. The $\mathrm{q}_{\mathrm{u}}$ of cement stabilized laterite bricks are consistently higher than that of ash stabilized bricks except at 14 days of curing when the $q_{u}$ of laterite bricks stabilized with 2, 4 and $8 \%$ ash are higher than that of cement stabilized bricks.

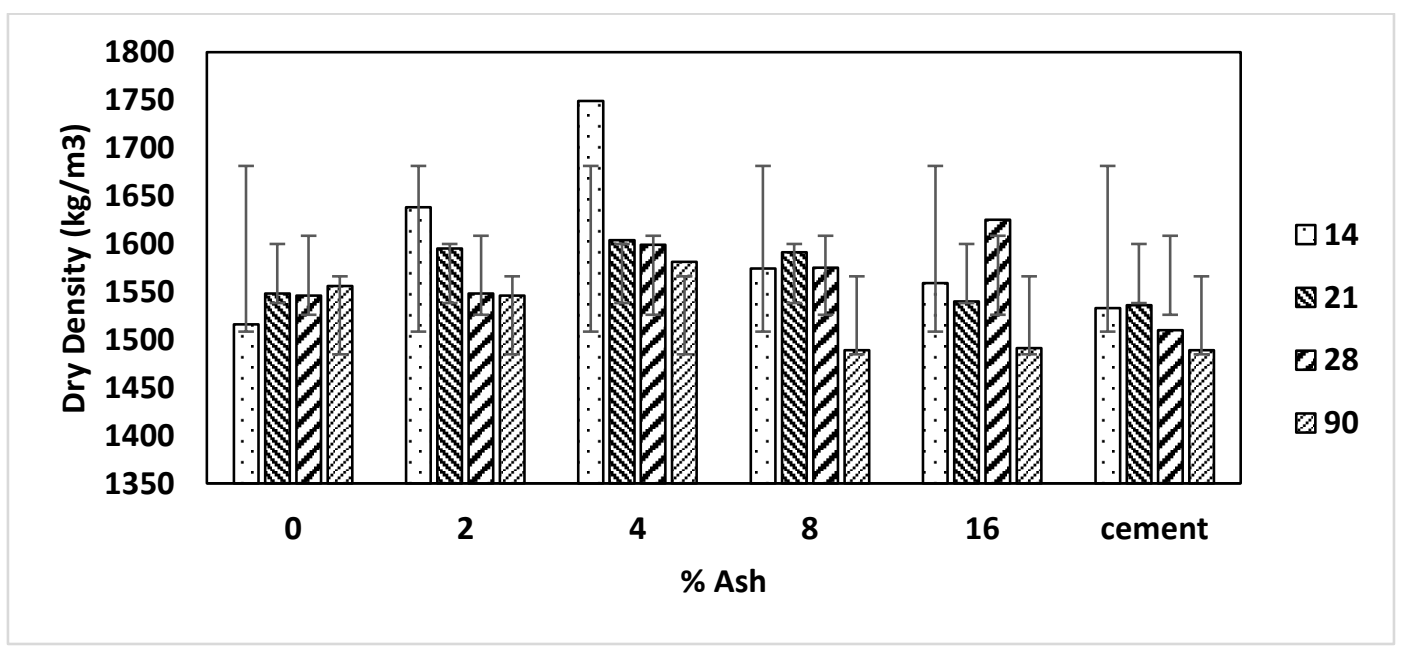

Figure 4: Dry density of stabilized laterite bricks at different concentrations 


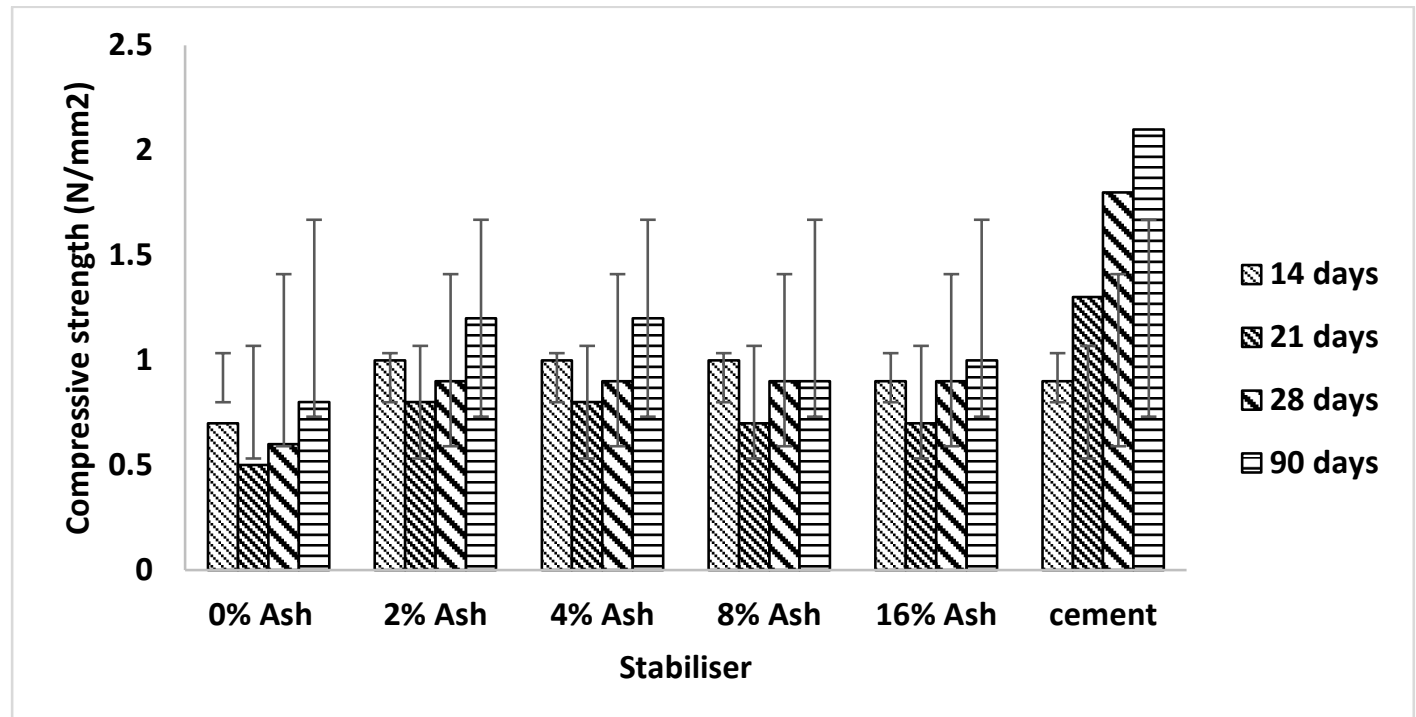

Figure 5: Compressive strengths of laterite bricks at different curing ages.

\section{CONCLUSION}

From the study, it can be concluded that saw dust ash (SDA) can be used as a pozollana because it contains high $\mathrm{SiO}_{2}$ content, egg shell ash (ESA) contains high calcium content, and the use of a combination of sawdust and eggshell ash is a viable alternative to the use of cement as a form of stabiliser for laterite bricks for low cost housing

\section{REFERENCES}

[1] Gidigasu M. D. Laterite Soil Engineering, Elsevier Scientific Pub. Co., Amsterdam, 1976.

[2] Ola, S.A. Geotechnical properties and behavior of some Nigerian lateritic soils," In: Tropical Soils of Nigeria in Engineering Practice, S. A. Ola Ed, A. A. Balkema, Rotterdam, 1983.

[3] Nicholson, P.G. and Kashyap, V. "Fly ash stabilization of Hawaiian soils." In: Fly Ash for Soil Improvement. (Ed) by Sharp K.D, Geotechnical Special Publication No.36, ASCE, New York. pp.15 - 29, 1993.

[4] Osinubi, K. J. 'Influence of compactive efforts and compaction delays on lime treated soils.' Journal of Transportation Engineering. Vol. 124, Number 2, pp 149- 155, 1998a.

[5] Osinubi, K. J. 'Permeability of lime treated lateritic soil.' Journal of Transportation. Engineering. A.S.C.E. Vol. 124. Number 5 , pp 465-469, $1998 \mathrm{~b}$.

[6] Osinubi K.J. "Laboratory trial of soil stabilization using pulverized coal bottom ash". NSE Technical Transactions, Vol. 35, No.4pp. 13, 2000.

[7] Osinubi K.J. "Stabilization of lateritic soil with cationic bitumen emulsion". Journal of Engineering Res., Vol. 9, Number 324, pp. 137-150, 2001.

[8] Chirag J., Vyom B and Rushabh A. A Study of Future Trend for Sustainable Development by Incorporation of Supplementary Cementitious Material's.
International Journal of Engineering and Science (IJIES) Vol. 1. Issue 11, pp 19-26, 2013.

[9] Enuoye, A. and Olanipekun, D. 'Effect of Rice Husk Ash and Lime on Lateritic Bricks'. Unpublished B.Sc. Thesis, Department of Civil Engineering, Obafemi Awolowo University, Ile-Ife, 2008.

[10] Bhaumik, R., N. K. Mondal, B. Das, P. Roy, K. C. Pal, C. Das, A. Banerjee, And Datta J. K. 'Eggshell Powder as an Adsorbent for Removal of Fluoride from Aqueous Solution: Equilibrium, Kinetic and Thermodynamic Studies" Coden Ecjhao E-Journal of Chemistry, Vol. 9, issue 3, pp 1457-1480, 2012.

[11] NBRRI. Requirement of laterite bricks BS 1377, Methods of Testing of Soil for Civil Engineering Purposes, British Standard Institute, London United Kingdom, 1990.

[12] Das B. M. Principle of geotechnical engineering, Stamford, CT: Thomson Learning College, Stamford, 2006.

[13] Mageswari M. and Vidivelli, B. "The use of sawdust ash as fine aggregate replacement in concrete", Journal of Environmental Research and Development, Vol. 3 Number 3, 2009.

[14] Ayodele, A. L. and Agbede, O. A. "Influence of electrochemical treatment on a typical laterite" Ground Improvement. Vol. 171, number 2, 2017, pp 103-111. Doi:10.1680/jgrim.16.0030

[15] Raheem, A. A. 'Comparism of the Quality of Sandcrete Blocks Produced by LAUTECH Block Industry with others within Ogbomoso Township', Science Focus, Vol. 11, Number 1, pp $103-108,2006$.

[16] Agbede, I. O. and Manasseh J. Use of cement-sand admixture in laterite brick production for low cost housing: Leonardo Electronic Journal of Practices and Technologies. Pp 163-174, 2008.

[17] Nigerian Industrial Standards. NIS 087: Specification for Sandcrete Blocks. Standard Organisation of Nigeria, 2000.

[18] ACI, Use of Raw or Processed Natural Pozzolans in Concrete. ACI Committee Reported 232, 2013. 